\title{
GIS Based Soil Erosion Estimation Using Rusle Model: A Case Study of Upper Kangsabati Watershed, West Bengal, India
}

\author{
Asish Saha ${ }^{1 *}$, Palash Ghosh ${ }^{1}$ and Biswajit Mitra ${ }^{2}$ \\ Ronald T Richards, Universidad del Este, Puerto Rico
}

Submission: July 19, 2018; Published: August 08, 2018

*Corresponding author: Ronald T Richards, Universidad del Este, Highway \#190 km 1.8, Carolina, Puerto Rico, Tel: 787-642-2365;

Email: richardsr1@suagm.edu

Abstract

An accelerated rate of soil erosion is a serious and continuous endemic environmental problem in the western part of West Bengal. The present study is carried out in the upper Kangsabati watershed of Puruliya district, West Bengal with an area of $276.19 \mathrm{~km}^{2}$. It is fact that the surface runoff of seasonal rainfall is more in this area due to its sloping terrain characteristics. Average annual soil erosion has been estimated based on the five parameters defined in the Revised Universal Soil Loss Equation (RUSLE) and with the help of Geographical Information technology. Overlay of five parameters, viz., rainfall-runoff erosivity factor (R), soil erodibility factor (K), slope length and steepness factor (LS), cover and management factor (C) and support and conservations practices factor (P) has been done in GIS platform. Potential average annual soil erosion of the watershed has been classified into four categories. The High rate of soil erosion (>13.42 tha-1 year -1$)$ was found along the northeastern part of the watershed. On the other side low amount of soil erosion ( $<1$ tha-1 year -1 ) was found along the hilly tract of dense forest cover and plantation areas.

Keywords: Rusle; Soil Erosion; GIS; Watershed; Terrain; Hilly Tract

\section{Introduction}

One of the serious and continuous endemic environmental problems is soil erosion and land degradation particularly in the third world country where agriculture is the main stay of the economy. More than $50 \%$ of the total area of India is affected by land degradation resulting from soil erosion [1]. Around the globe every year more than 75 billion tons of soil is removed from agricultural land due to erosion [2]. Erosion is the progressive removal of soil or rock particles from the parent mass by a fluid agent [3]. The forms of soil erosion are mainly sheet, rill and gully erosion. Intensity of this erosion widely varies spatially and temporally depending on morpho-climatic and pedo-geomorphic factors [4]. The amount of soil erosion is measured on the basis of two models viz., physical based and empirical based model. GIS and remote sensing (RS) provide spatial input data to the empirical model and predict the potential soil erosion rate. By using the different type of models many scholars have worked on soil erosion throughout the world [5-9]. The most commonly used empirical model is Universal Soil Loss Equation (USLE) developed by Wischmeier and Smith in 1965 for measuring sheet and rill erosion [6]. Revised Universal Soil Loss Equation (RUSLE) uses the same empirical principles as USLE; however, it includes numerous improvements, such as monthly factors, incorporation of the influence of profile convexity/concavity using segmentation of irregular slopes, improved empirical equations for the computation of LS factor $[10,11]$. In this study, IRS LISS III image has been used for generating $\mathrm{C}$ factor by using Normalized Difference Vegetation Index (NDVI). The present study is an attempt to focus on the estimation of soil erosion in the upper Kangsabati watershed by RUSLE model.

\section{Location and Description of the Study Area}

The upper Kangsabati (also known as Kasai) watershed is located in Puruliya district in the state of West Bengal, India (Figure 1). It is extended between $23^{\circ} 13^{\prime} 26^{\prime \prime} \mathrm{N}$ to $23^{\circ} 28^{\prime} 33^{\prime \prime} \mathrm{N}$ latitude and $85^{\circ} 17^{\prime} 18^{\prime \prime} \mathrm{E}$ to $86^{\circ} 11^{\prime} 56^{\prime \prime}$ E longitude. The catchment area of the study site is about $276.19 \mathrm{~km} 2$. The river originates near Jhalda of Puruliya district. Regionally the study area is part of Chotanagpur Gneissic Complex (CGC), in which rock formation belongs to Archaean age, which is the oldest rock formation of the district [12]. The soils in the study area are mainly fine-loamy, coarse-loamy and loamy-skeletal (ICAR, 1991). The average annual rainfall in this watershed is 1393 $\mathrm{mm}$ and the annual mean temperature is $25.6^{\circ} \mathrm{C}$ with mean summer and mean winter temperature are $29.0^{\circ} \mathrm{C}$ and $21.3^{\circ} \mathrm{C}$ respectively [13]. Topographically the area is characterized by undulating rugged hilly terrain exhibiting highly dissected pedimental landscape and lateritic upland with skeletal soil. 


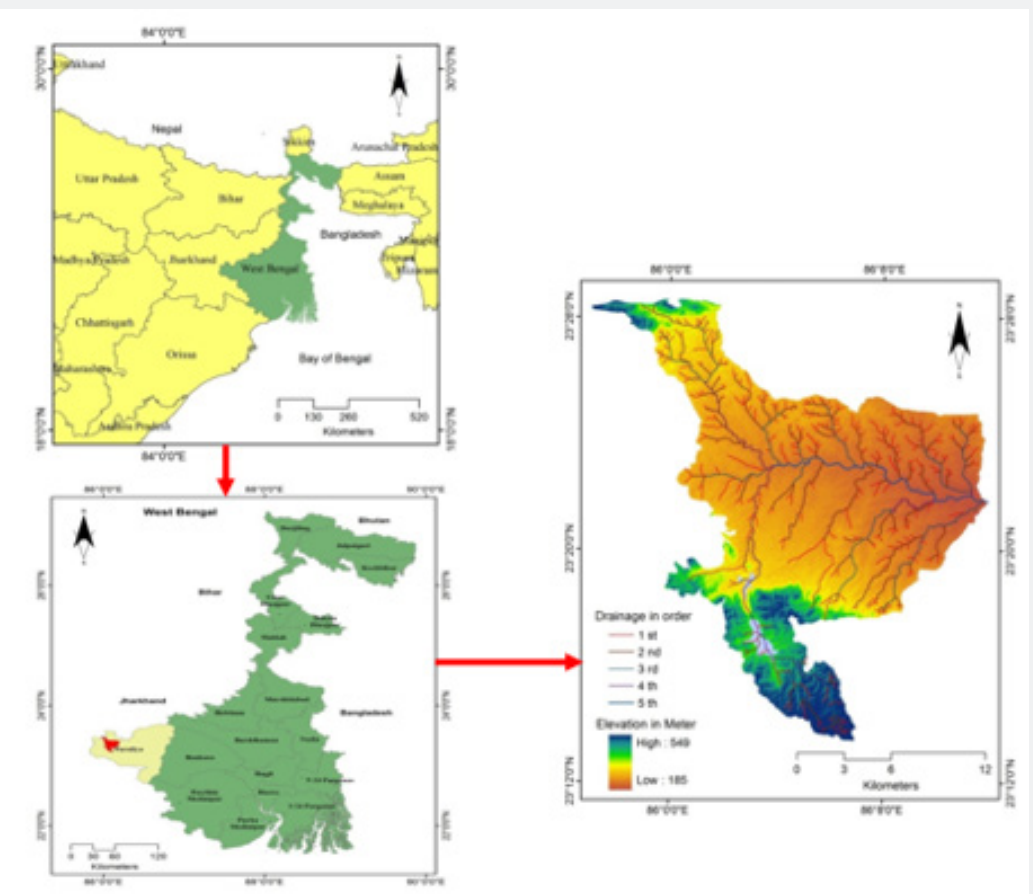

Figure 1: Location map of the upper Kangsabati watershed.

\section{Materials and Methods}

In this study, GIS plays a major role to prepare different types of thematic map and estimation of soil erosion rate. For the present study different type of data are collected from different sources. These are mainly numerical data, thematic maps etc, which help to analysis the research work. Rainfall data of five years (2012-2016) obtained from India Meteorological Department (IMD), soil data obtained from National Bureau of Soil Survey and Land Use Planning (ICAR, 1991). Topographical sheets (73I/3, 73I/4, and 73E/15, scale of 1:50000) published by Survey of India (SOI), Shuttle Radar Topography Mission (SRTM) $30 \mathrm{~m}$ resolution and IRS LISS III satellite image have been used for the study. ArcGIS 10.3 and ERDAS Imagine 14.0 are used for the creation of a digital database, data integration and analysis. After correction the DEM in GIS platform, it has been used to prepare the slope map. Later DEM and slope map are used to prepare LS factor. IRS LISS III data along with topographical sheets have been used to prepare detailed land use land cover (LULC) map.

\section{Soil Erosion Estimation Model RUSLE}

The Revised Universal Soil Loss Equation (RUSLE) model has been adopted to estimate the annual soil loss and the equation (Equation 1) is as:

$$
A=R X K X L X S X C X P
$$

Where, $\mathrm{A}$ is the average annual soil loss per unit area expressed in tones/ha/year ( $\mathrm{t}$ ha- 1 year ${ }^{-1}$ ); $\mathrm{R}$ is the rainfallrunoff erosivity factor (MJ $\mathrm{mm}$ ha- $1 \mathrm{~h}^{-1}$ ); $\mathrm{K}$ is soil erodibility factor ( $\mathrm{t}$ ha $\mathrm{h} \mathrm{MJ-1} \mathrm{mm-1)}$; $\mathrm{L}$ is the slope length factor; $\mathrm{S}$ is the slope steepness factor; $\mathrm{C}$ is the cover and management factor and $\mathrm{P}$ is the support and conservation practices factor. Flowchart (Figure 2) showing the methodology adopted in this research study.

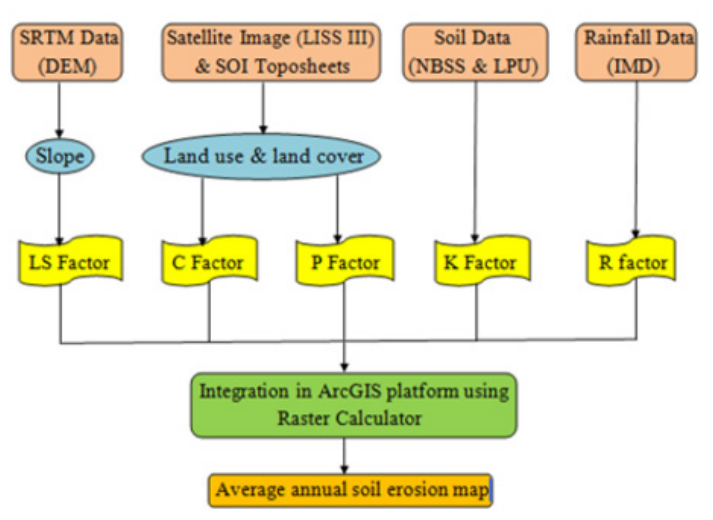

Figure 2: Flow chart for the preparation of potential soil erosion map. 


\section{Rainfall Erosivity Factor (R)}

Rainfall erosivity factor is the annual total value of the erosion index (EI30) for a location [14]. Rainfall intensity represents the principal factor of kinetic energy and to estimate the rainfall erosivity [15]. If the intensity and duration of rainfall increase the value of $\mathrm{R}$ factor also increases. In this study, [16] established empirical equation (Equation 2) which has been used for estimating annual rainfall erosivity. The linear relationship of erosion index is:

$$
R a=79+0.363 X P
$$

Where, Ra is the average annual rainfall erosivity factor (MJ $\mathrm{mm}$ ha- $1 \mathrm{~h}-1)$ and $\mathrm{P}$ is the rainfall ( $\mathrm{mm})$. The average annual rainfall data recorded by India Meteorological Department (IMD), Pune, at three rain-gauge stations located in the surrounding area of upper Kangsabati watershed for over a span of five years (2012-2016) has been used for calculating R factor (Table 1). Spatial distribution of $\mathrm{R}$ factor has been obtained using Inverse Distance Weighted (IDW) interpolation techniques.

Table 1: Average annual rainfall $(\mathrm{mm})$ and calculated rainfall-runoff erosivity factor $(\mathrm{R})$ of three rainfall gauging station located in surrounding area of the upper Kangsabati watershed.

\begin{tabular}{|c|c|c|c|}
\hline \multirow{2}{*}{ Station } & \multirow{2}{*}{ Coordinates } & Average Annual (2012 - 2016) \\
\cline { 3 - 4 } & & Rainfall (mm) & R-Factor \\
\hline Near to Jhalda & $23^{\circ} 22^{\prime} \mathrm{N} 85^{\circ} 59^{\prime} \mathrm{E}$ & 1367.9 & 575.55 \\
\hline Para & $23^{\circ} 32^{\prime} \mathrm{N} 86^{\circ} 31^{\prime} \mathrm{E}$ & 1481.1 & 616.64 \\
\hline Near to Bagmandi & $23^{\circ} 12^{\prime} \mathrm{N} 86^{\circ} 02^{\prime} \mathrm{E}$ & 1408.7 & 590.36 \\
\hline
\end{tabular}

\section{Soil Erodibility Factor (K)}

Soil erodibility factor is a measure of potential erodibility of soil and it depends on the inherent properties of the soil. The $\mathrm{K}$ factor is related to the integrated effects of rainfall, runoff and infiltration on soil loss, accounting for the influences of soil properties on soil loss during storms action on uplands areas [17]. Taking into consideration the Soil texture, organic matter and permeability soil erodibility factor $(\mathrm{K})$ has been calculated. Based on the map produced by National Bureau of Soil Survey and Land Use Planning [18] for the district of Puruliya, K values of different soil type in the study area have been estimated. Thirteen types of soil classes (Table 2) in the study area have been identified and values are imputed to respective classes of soil.

Table 2: Soil erodibility factor $(K)$ values of upper Kangsabati watershed.

\begin{tabular}{|c|c|}
\hline Soil Textural Class & K Factor \\
\hline Clay & 0.220 \\
\hline Clay loam & 0.300 \\
\hline Coarse sandy loam & 0.070 \\
\hline Fine sand & 0.080 \\
\hline Fine sandy loam & 0.180 \\
\hline Loam & 0.300 \\
\hline Loamy fine sand & 0.110 \\
\hline Loamy very fine sand & 0.390 \\
\hline Very fine sand & 0.430 \\
\hline Very fine sandy loam & 0.350 \\
\hline Silt loam & 0.380 \\
\hline Silty clay & 0.260 \\
\hline Loamy sand & 0.040 \\
\hline
\end{tabular}

\section{Topographic Factor (LS)}

Topographic factor includes slope length factor (L) and slope steepness factor $(\mathrm{S})$ which mainly reflect the effect of surface topography on erosion by water action $[19,20,14]$. Slope length (L) and slope steepness (S) have been derived by using SRTM DEM (30 m resolution) in ArcGIS 10.3 platform. Slope length factor (L) has been calculated on the basis of following equation (Equation 3) given by [21] which is:

$$
L=\left(\frac{\lambda}{22.13}\right) m
$$

Where, $\mathrm{L}$ is the slope length factor; $\lambda$ is the slope length in meter; $\mathrm{m}$ is the variable slope-length exponent. 22.13 is the RUSLE unit plot length in the meter. The slope steepness factor (S) is evaluated based on the relationship (Equations 4.1, 4.2) given by [21] for slope length longer than 4 meters:

$$
\begin{aligned}
& S=10.8 \sin \phi+0.03 \text { when } s<9 \% \\
& S=16.8 \sin \theta-0.05 \text { when } s \geq 9 \%
\end{aligned}
$$

Where, $\mathrm{S}$ is the slope steepness factor which is dimensionless and $\theta$ is the slope angle in degree. 
The LS factor is calculated by multiplying $\mathrm{L}$ and $\mathrm{S}$ factor together (Moore and Burch, 1986) in raster calculator in ArcGIS platform with the help of following equation (Equation 5):

$$
L S=\operatorname{Power}\left(\text { flowaccumulation } * \frac{\text { cell size }}{22.13}, 0.4\right) * \operatorname{Power}\left(\frac{\sin (\text { slope } 0.01745)}{0.09}, 1.4\right) * 1.4
$$

\section{Cover - Management Factor (C)}

The cover and management factor is dimensionless which is an important factor for reduction of soil erosion and it depends on land use pattern of an area [22,23]. The C factor is the ratio of soil loss from an area with protective cover and management to soil loss in the continuous clean tilled fallow land [24]. The values of $\mathrm{C}$ factor vary from 0 to 1 based on land use land cover types excluding areas of water body [25]. Land use land cover map (Figure 3) of the study area has been prepared with the help of LISS III image and toposheets (SOI) which is the primary determining for estimation of $\mathrm{C}$ factor. In this study, Normalized Difference Vegetation Index (NDVI) was used to calculate the C factor. The equation (Equation 6) for calculating the NDVI (Rouse et al. 1974) is:

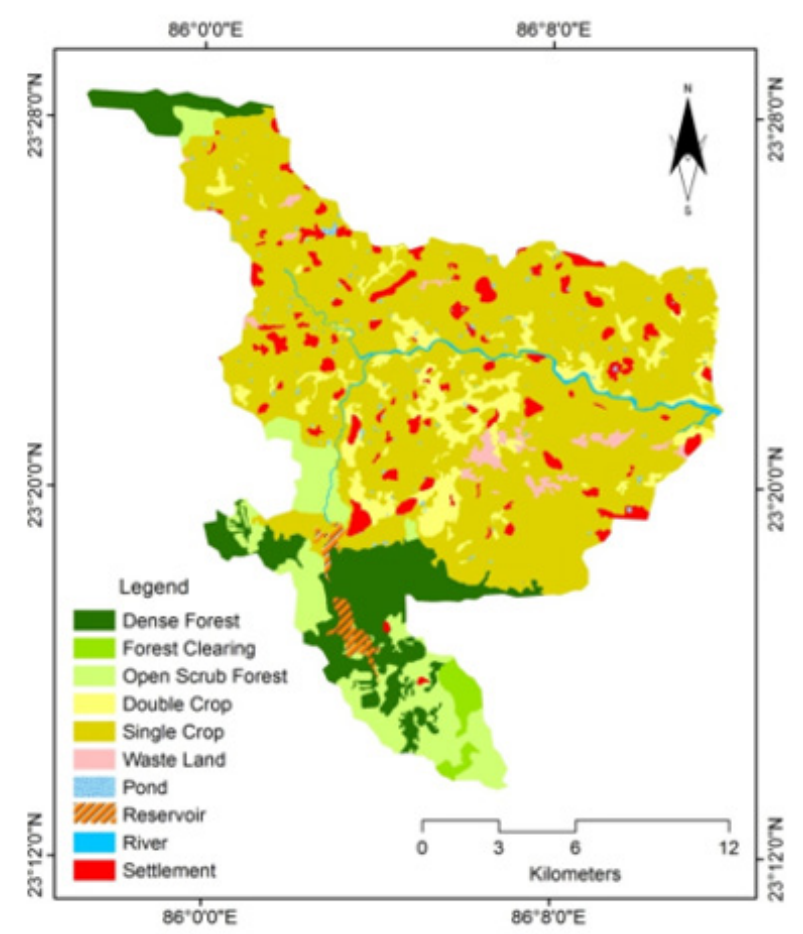

Figure 3: Land use land cover map of the study area.

$$
N D V I=(N I R-R E D) /(N I R+R E D)
$$

After producing NDVI image, following equation (Equation 7) has been used to create $C$ factor map and this is:

$$
C=1.20-1.21 * N D V I
$$

\section{Support Practice Factor (P)}

The support practice factor (P) is the most important parameter in RUSLE method and it is a dimensionless factor [24] defined $\mathrm{P}$ factor as the ratio of soil loss in a particular support practice to the corresponding soil loss with up and downslope cultivation. P-value ranges from 0 to 1 , where the value 0 indicates good erosion resistant facility made by man and the value 1 indicate an absence of erosion resistant facility. From the previous study it has been assigned that land with $P$ value of 0.28 as agricultural land and land with $P$ value of 1.0 as non

\section{Result and Discussion}

\section{Spatial Distribution of Soil Erosion Factors}

The average annual rainfall erosivity factor (R) for the years 2012 - 2016 vary in the ranges of 575.55 to $616.64 \mathrm{MJ}$ $\mathrm{mm} \mathrm{ha} \mathrm{h}^{-1} \mathrm{~h}^{-1}$. The $\mathrm{R}$ factor map (Figure $4 \mathrm{a}$ ) showing that the downstream portion or eastern part of the study area has high rainfall erosivity because this area received the highest amount of rainfall. On the other hand, northwestern and southern parts of the watershed have low rainfall erosivity due to slightly low rainfall and presence of vegetal cover. The rate of soil erodibility is very high if the soil texture is fine. Presence of organic matter into the soil is a dominant controlling factor of soil erodibility. It is established fact that soils with less than $3.5 \%$ organic matter are considered to be erodible [26,27]. In the study area, the value of $\mathrm{K}$ factor ranges from 0.040 to 0.430 (Figure 4b). Very fine sand, sandy loamy and silt loamy having a higher value 
of $\mathrm{K}$ in the study area which is more prone to erosion. Upper northeastern part of the study area is more vulnerable to erosion where $\mathrm{K}$ value ranges from 0.321 to 0.430 . On the contrary, in the high relief area and middle part of the study area $\mathrm{K}$ value is low (0.040 to 0.200$)$. In the upper Kangsabati watershed, the range of elevation varies from $185 \mathrm{~m}$ to $549 \mathrm{~m}$ (Figure $5 \mathrm{a}$ ). It is mention that higher the LS value greater the potentiality to erosion. Based on the LS value the whole study area classified into four categories where values range from 0.00 to 14.00 (Figure 5b). The most part of the watershed is characterized by low value of LS factor but here as a matter of fact that the rate of soil erosion is moderate to very high due to high drainage density. Land use land cover map of the study area may be classified into ten categories, where settlement area, agricultural land, and wasteland are more prominent in the erosion-prone zone. $\mathrm{C}$ factor in the study area has been computed by using NDVI. The value of $\mathrm{C}$ factor ranges from 0.00 to 0.44 (Figure 6a). $\mathrm{P}$ factor generally depends on different practices which have been undertaken for control of soil erosion. At the time of field visit in the study area, it has been found that farmers are practicing some conservation method like creating bunds, gully plugging around the agricultural field. In addition, efforts are on to increase the vegetal cover by using percolation tanks, minor irrigation tanks. In this study P factor (Figure 6b) values are taken in two type viz., agricultural field (0.28) and non-agricultural field (1.0). agricultural land $[28,24,29]$.
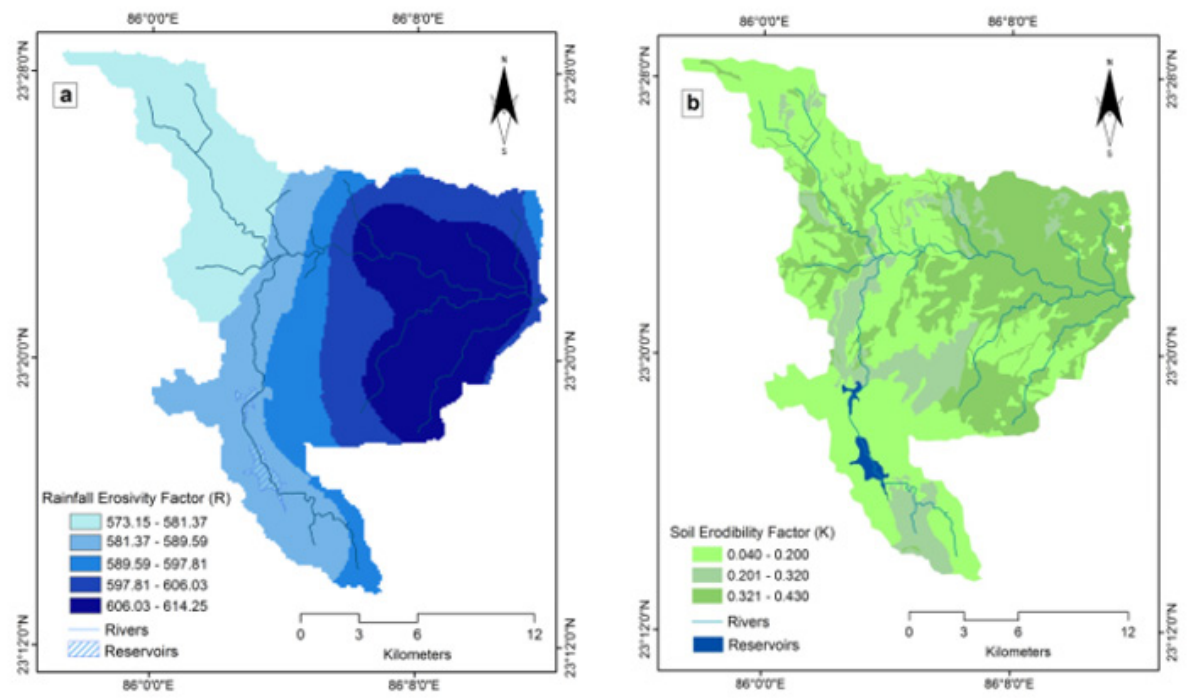

Figure 4: a) Rainfall erosivity factor (R) map and b) Soil erodibility factor (K) map of the study area.
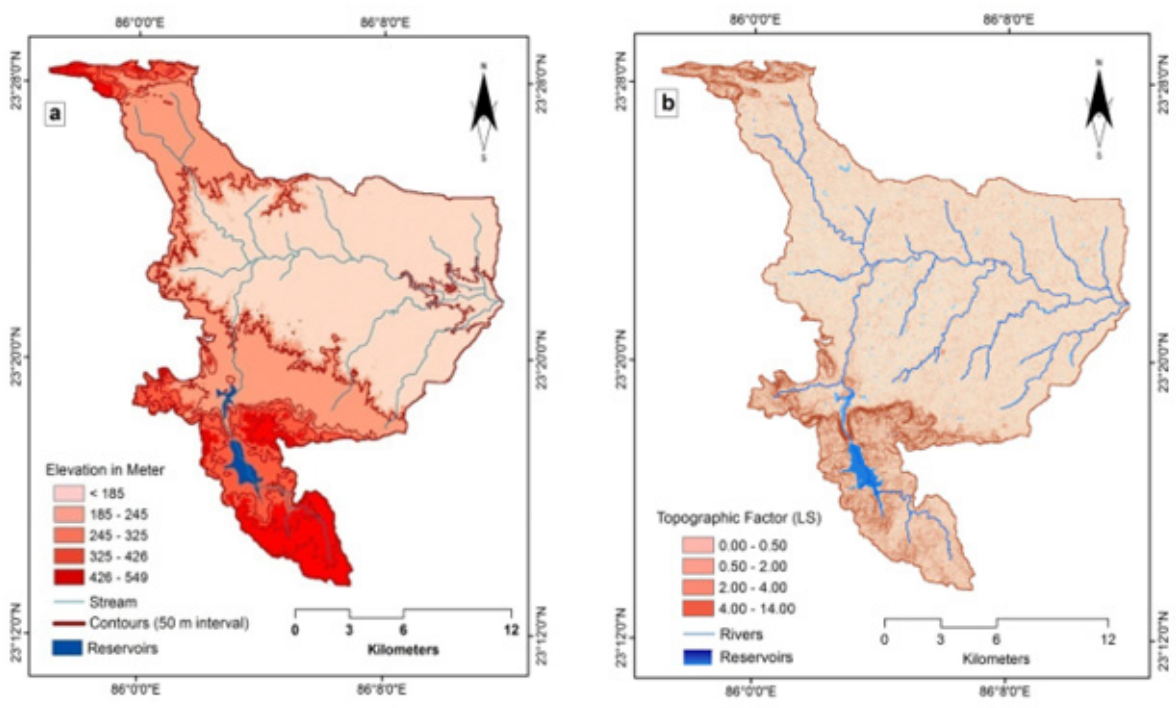

Figure 5: a) Elevation map and b) Length and slope factor (LS) map of the study area. 

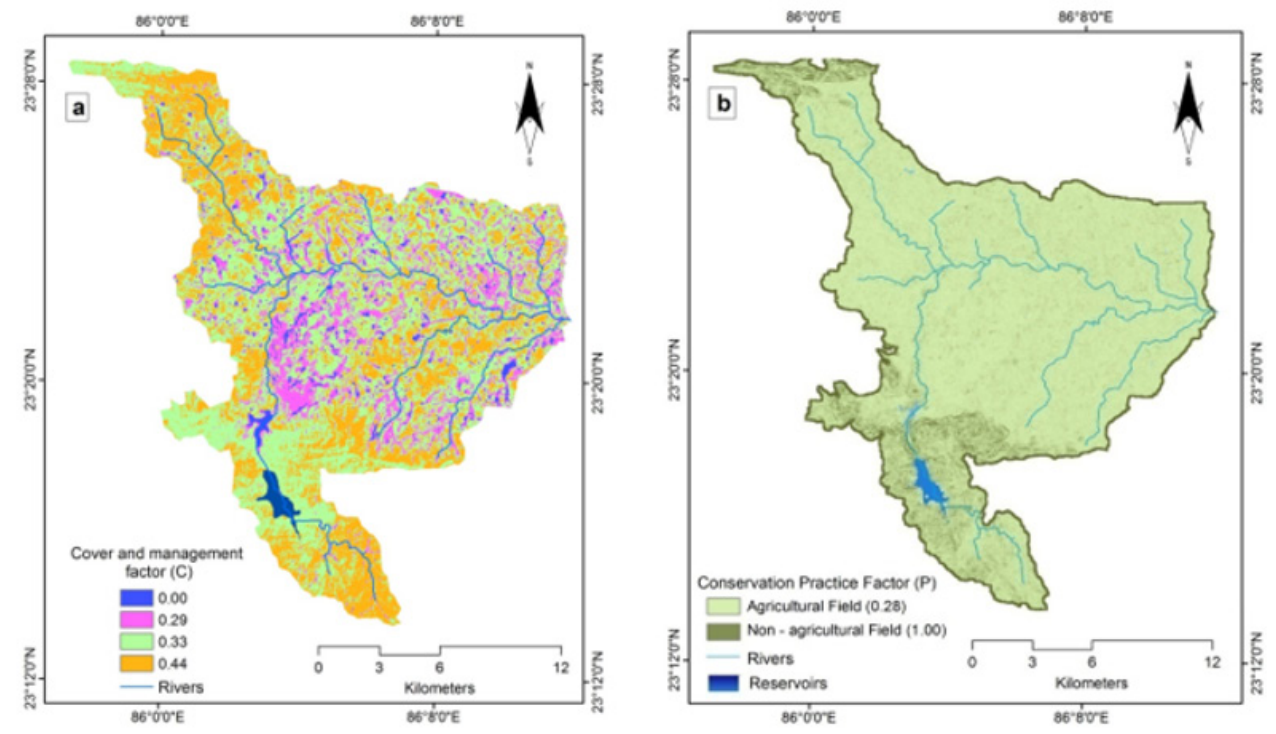

Figure 6: a) Crop and management factor $(C)$ map and b)Conservation practice factor $(P)$ map of the study area.

\section{Estimation of Potential Soil Erosion (A)}

The Revised Universal Soil Loss Equation (RUSLE) is an empirically based model and has been used to generate the potential soil erosion map by multiplying its five factors in raster format. The potential soil erosion of the upper Kangsabati watershed varies from $<0.014$ to $13.42 \mathrm{t} \mathrm{ha}^{-1}$ year $^{-1}$ (Figure 7) and it is classified into four soil erosion zones. These zones are low $\left(<0.014\right.$ t ha $^{-1}$ year $\left.^{-1}\right)$, moderate $\left(0.014^{-1} .0\right.$ t ha $^{-1}$ year $\left.^{-1}\right)$, high $\left(1.0\right.$ - $5.0 \mathrm{t} \mathrm{ha}^{-1}$ year $\left.^{-1}\right)$ and very high prone zone $(5.0-13.42 .0 \mathrm{t}$ ha-1 year ${ }^{-1}$ ). In the whole watershed it is found that nearly $45 \%$ area is under very high and high erosion prone zone [30-36].

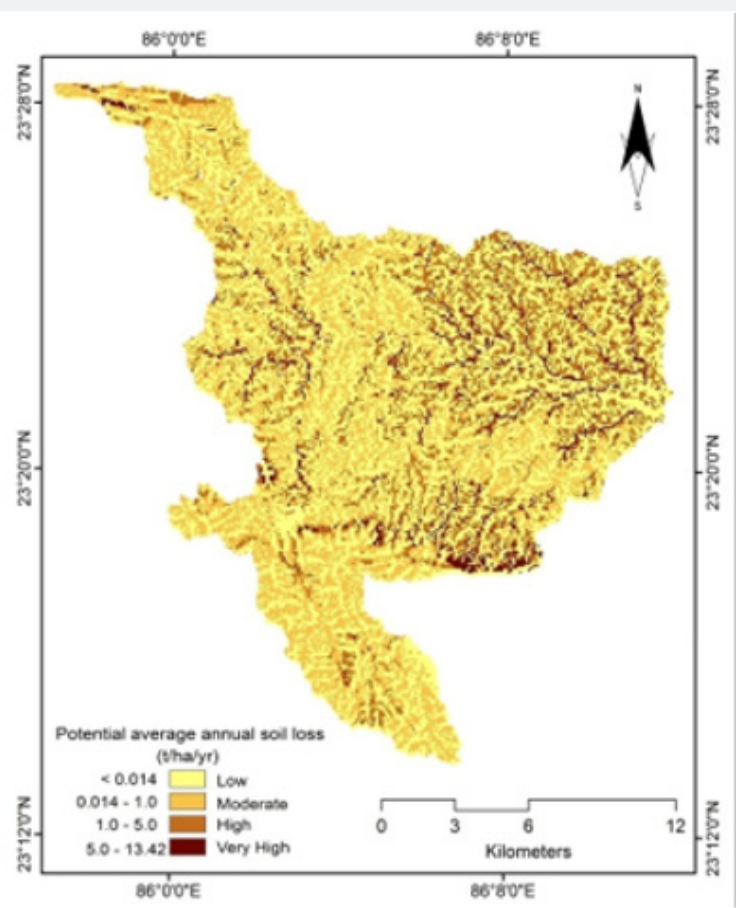

Figure 7: Average annual soil erosion map of the upper Kangsabati watershed.

\section{Conclusion}

The Revised Universal Soil Loss Equation (RUSLE) is a very useful technique to quantitatively measure the average annual soil erosion in a watershed. To estimate the spatial distribution of soil erosion prone zone, RUSLE model could be integrated with GIS techniques. Various thematic layers were generated 
for the study area using various tools available in GIS techniques to find out the result. In the upper Kangsabati watershed, very high and high amount of soil erosion prone zone is observed in northeastern part of valley fill and intervalley fill of single crop lands where drainage density is high. On contrary, low and moderate soil erosion zone observed in the hilly tract with dense forest and open scrub forest covered areas. The land use land cover changes have an effect on increasing soil erosion rate. With the passage of time clearing of forest cover in the hilly track and changes in crop patterns have an effect to increasing soil erosion rate. Thus, in the hilly areas where clearing of forest has been cleared off, soil conservation practices must be adopted to control soil erosion. In the agricultural areas, soil conservation practices like terracing, agro-forestry, bunding, crop rotation etc. techniques must be adopted with more precise method for soil conservation. It is observed that large part of the watershed is sloping plain land which has a slope up to $5^{\circ} \mathrm{C}$. The land is mostly used for single crop agriculture and it is the land of maximum soil erosion. This zone has maximum number of $1^{\text {st }}$ and $2^{\text {nd }}$ order streams for which rate of soil erosion is high. If soil erosion from the agricultural land continues at present rate, then it may lead to soil degradation and ultimately cultivable land will become unfit for cultivation. Rate of erosion may increase in future due to continuous forest degradation for extension of agricultural land and to some extent over grazing. To overcome these problems different type of soil and water conservation measure is necessity as soon as possible.

\section{References}

1. Sehgal J, Abrol IP (1994) Soil degradation in India: status and impact. Oxford and IBH publihsing co, New Delhi, India p. 80.

2. Pandey A, Mathur A, Mishra SK, Mal BC (2009) Soil erosion modeling of a Himalayan watershed using RS and GIS. Environ Earth Scis 59(2): 399-410.

3. Strahler AN (1964) Quantitative geomorphology of drainage basin and channel networks. In Chow VT (edn.); Handbook of applied hydrology. McGraw-Hill, New York, USA pp. 439-476.

4. Ghosh S, Maji T (2011) Pedo geomorphic analysis of soil loss in the lateritic region of Rampurhat I block of Bhirbhum district, West Bengal and Shikaripara block in Dumka district, Jharkhand. Int J Environ sci 1(7): 1734 -1750.

5. Demirci A, Karaburan A (2012) Estimation of soil erosion using RUSLE in a GIS framework: A case study in the Buyukcekmece lake watershed, northwest Turkey. Environ Earth Sci 66(3): 903-913.

6. Ganasri BP, Ramesh H (2016) Assessment of soil erosion by RUSLE model using remote sensing and GIS- a case study of Nethravathi basin. Geosci Front 7(6): 953-961.

7. Kouli M, Soupios P, Vallianatos F (2009) Soil erosion prediction using the revised universal soil loss equation (RUSLE) in a GIS framework, Chaina, northwestern Crete, Greece. Environ Geol 57(3): 483-497.

8. Zhou W, Wu BF (2008) Assessment of soil erosion and sediment delivery ratio using remote sensing and GIS: a case study of upstream Chaobaihe river catchment, North China. Int J Sediment Res 23(2): 167-173.

9. Samanta S, Koloa C, Pal DK, Palsamanta B (2016) Estimation of potential soil erosion rate using RUSLE and E30 model. Model Earth Syst Environ 2(3): 149.
10. Foster GR, Wischmeier WH (1974) Evaluating irregular slopes for soil loss prediction. Trans Am Soc Agric Eng 17: 305-309.

11. Renard KG, Foster GR, Weesies GA, Porter JP (1991) RUSLE, Revised Universal Soil Loss Equation. J Soil Water Conserv 46(1): 30-33.

12. Haldar S, Saha P (2015) Identifying the causes of water scarcity in Purulia, West bengal, India- a geographical perspective. IOSR J Environ Sci 9(8): 41-51.

13. Saini K, Deb T, Mitra P, Ghatol S (1999) Assessment of degraded lands of Purulia district, West Bengal using remotely sensed data. J Indian Soc Remote sens 27(1): 23-30.

14. Sarkar D, Nayak D, Dutta D, Dhyani B (2005) Soil erosion of West Bengal. NBSS Publ. No. 117, NBSS \& LUP (ICAR), Nagpur, India.

15. Balasubramani K, Mohan V, Kumaraswamy K, Saravanabavan V (2015) Estimation of soil erosion in a semi-arid watershed of tamil Nadu (India) using revised universal soil loss equation (rusle) model through GIS. Model earth Syst Environ 1(3): 1-17.

16. Singh G, Rambabu VV, Chandra S (1981) Soil loss prediction research in India. Bulletin of Central Soil and Water Conservation Research and Training Institute, $\mathrm{T}_{12} / \mathrm{D} 9$, Dehradun.

17. Renard KG, Foster GR, Weesies GA, McCool DK, Yoder DC (1997) Predicting soil erosion by water: a guide to conservation planning with the revised universal soil loss equation (RUSLE), US Govt. Printing Office, Washington, DC, USA.

18. ICAR (1991) West Bengal soils National Bureau of Soil Survey and Land Use Planning (ICAR) Regional Centre Kolkata and in co-operation with Dept of Agriculture, Govt of West Bengal, Kolkata, India.

19. Yildirim U (2012) Assessment of soil erosion at the Deðirmen Creek watershed area, Afyonkarahisar, Turkey, pp. 73-80.

20. Shit P, Nandi AS, Bhunia GS (2015) Soil erosion risk mapping using RUSLE ON jhargram sub-division at West Bengal in India. Model earth Syst Environ 1(3): 28.

21. Mc Cool DK, Brown LC, Foster GR, Mutchler CK, Meyer LD (1987) Revised slope steepness for the Universal Soil Loss Equation. Trans ASAE 30(5): 1387-1396.

22. Pal S, Shit M (2017) Application of RUSLE model for soil loss estimation of Jaipanda watershed, West Bengal. Spat Inf Res 25(3): 399-409.

23. Beskow S, Mello CR, Norton LD, Cur N, Viola MN, et al. (2009) Soil erosion prediction in the Grand River Basin, Brazil using distributed modelling. Catena 79(1): 49-59.

24. Pandey A, Chowdary VM, Mal BC (2007) Identification of critical erosion prone areas in the smallagricultural watershed using USLE, GIS and Remote Sensing. Water Resour Manag 21: 729-746.

25. Karaburun A (2010) Estimation of C factor for soil erosion modeling using NDVI in Buyukcekmece watershed. Ozean J Appl Sci 3(1): 77-85.

26. Kumar S, Kushwaha SPS (2013) Modelling soil erosion risk based on RUSLE-3D using GIS in a Shivalik sub-watershed. J Earth Syst Sci 122(2): 389-398.

27. Evans R (1980) Mechanics of water erosion and their spatial and temporal controls: an empirical viewpoint. In Soil Erosion, Wiley, New York, USA pp. 109-128.

28. Rao YP (1981) Evaluation of cropping management factor in Universal Soil Loss Equation under natural rainfall condition of Kharagpur, India. In: Proceedings of the South-east Asian Regional Symposium on Problems of Soil Erosion and Sedimentation, Bangkok 27-29: 241254.

29. Parveen R, Kumar U (2012) Integrated approach of universal soil loss equation (USLE) and geographical information system (GIS) for soil 
loss risk assessment in Upper South Koel Basin, Jharkhand. J Geogr Inf Syst 4: 588-596.

30. Ghosh K, De SK, Bandyopadhyay S, Saha S (2013) Assessment of soil loss of the Dhalai River Basin, Tripura, India using RUSLE. Int J Geosci 4(1): 11-23.

31. Moore ID, Burch GJ (1986) Physical basis of the length-slope factor in the universa ISoi lloss Equation. Soil Sci Soc Am J 50(5): 1294-1298.

32. Prasannakumar V, Vijith H, Abinod S, Geetha N (2012) Estimation of soil erosion risk within a small mountainous sub- watershed in Kerala, India, using Revised Universal Soil Loss Equation (RUSLE) and geo-information technology. Geosci Front 3(2): 209-215.

33. Rouse JJ, Haas RH, Schell JA, Deering DW (1974) Monitoring vegetation system in the great plain with ERTS. NASA special publications, pp. 309-317.

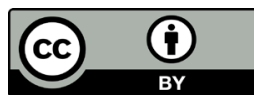

This work is licensed under Creative Commons Attribution 4.0 License

DOI: $10.19080 /$ IJESNR.2018.13.555871
34. Shi ZH, Cai CF, Ding SW, Wang TW, Chow TL (2004) Soil consevation planning at the small watershed level using RUSLE with GIS: A case study in the Three Gorge Area in China. Catena 55: 38-48.

35. USDA-SCS (US Dept of Agriculture Soil Conservation Service) (1972) SCS National Engineering Handbook, Section 4, Hydrology. Chapter 10, Estimation of Direct Runoff From Strom Rainfall. US Dept of Agriculture, Soil Conservation Service, Washington DC, p. 10-24.

36. Wischmeier WH, Smith DD (1965) Predicting rainfall-erosion losses from cropland east of the Rocky Mountains, guide for selection of practices for soil and water conservation. Agriculture handbooks, US Govt.print office, washington, USA.

\section{Your next submission with Juniper Publishers} will reach you the below assets

- Quality Editorial service

- Swift Peer Review

- Reprints availability

- E-prints Service

- Manuscript Podcast for convenient understanding

- Global attainment for your research

- Manuscript accessibility in different formats ( Pdf, E-pub, Full Text, Audio)

- Unceasing customer service

Track the below URL for one-step submission https://juniperpublishers.com/online-submission.php 